\title{
Luisa Nardini
}

The University of Texas, Austin

https://orcid.org/0000-0002-8465-3150

nardini@utexas.edu

\section{Medieval Chant and Digital Technology: A Website for Liturgical Prosulas}

Digital technology can enhance our understanding of medieval culture in general and of liturgical chant in particular in ways that might not be fully possible through traditionally printed resources. In the last few decades multiple databases for liturgical repertories as well as countless digital editions of medieval manuscripts have emerged to the point that is almost impossible today to pursue chant research without the recourse to internet-based tools. ${ }^{1}$ In addition to provide resources for the study of liturgical chant, however, digital technology also allows epistemological paths that can lead to a better understanding of specific features of liturgical chants. The non-linear, expansive, and modular nature of hypertextual reading, for instance, well exemplifies the open-ended conception of many liturgical genres. Liturgical tropes, in particular, which are musical and textual expansions of preexisting chants, can be very aptly represented by multimedia and

* On this subject I have presented some poster presentations at the following conferences: the Meeting of the American Musicological Society, Minneapolis (MN), November 2020; Society for Christian Scholarship in Music, Baylor University, February 2020; the American Musicological Society - Southwest Chapter, University of Houston, February 2020; and Digital Frontiers Conference Tear down the Walls, The University of Texas, Austin, September 2019. I thank Spencer Keralis and John Martin for authorizing me to withdraw it from the Digital Frontiers conference proceedings.

1 Among the myriad resources, I would just cite two of the most widely used databases: the Cantus Manuscript Database: Inventories of Chant Sources," Cantus Manuscript Database: Inventories of Chant Sources, http://cantus.uwaterloo.ca/ and Medieval Music Manuscripts Onli$n e$, http://musmed.eu/(21.04.2021). With slightly different criteria, both websites give access to a wide variety of chant sources and are cross-referenced. The Medieval Digital Resources: A Curated Guide and Database, published on the site of the Medieval Academy of America provides a peer-reviewed list of resources on music: http://mdr-maa.org/ (24.06.2021). "The Journal of the American Musicological Society" routinely publishes reviews of digital resources, many on medieval subjects. 
digital editions that exploit the very nature and resources of the medium to allow for a better representation of the genre's features.

Chants, Hypertext, and Prosulas (http://www.chanthypertexts.org/) is a companion website for a forthcoming book driven by the main goal to make an extensive body of liturgical prosulas - a form of tropes - more widely available. ${ }^{2}$ It contains full textual and musical transcription as well as photographic reproductions of medieval manuscripts and is conceived so that hyperlinks and textual annotations enhance the understanding of this body of medieval chant. It employs free platforms and servers, unveils aspects of cultural and gender diversity in music and book production in medieval southern Italy, and strives for ethical collaboration.

What is a hypertext? Before delving into the description of prosulas, it is useful to definea "hypertext" as a text that is displayed on a digital screen with links that lead to additional content in other pages or websites. It allows for reading paths that are non-linear, non-replicable, and multidirectional. In many respects, a hypertext can be likened to the page of a liturgical manuscript in that they both contain multimedia materials that are also interconnected with other textual and non-textual entities by way of intertextual associations. It is in virtue of these epistemological similarities, that the website, currently under construction, is conceived so that hyperlinks and textual annotations can enhance the understanding of medieval prosulas. ${ }^{3}$

What are prosulas? They are short texts that were added to pre-existing melismas (long melodies) of chants for the rites of Mass and Office. These small texts, which are mostly found in manuscripts from the tenth and the fourteenth centuries, add new content to the original liturgical chants, while also changing their style. Example 1 shows how the melody on the word "Alleluia" of the parent chant is reworked by adding a new text "Allevatus dominus." In some cases, assonances (in this case on the "alle-" of the words "alleluia" and "allevatus") reinforce sonic and epistemological interconnections between the text of the parent chant and that of the prosula. This particular prosula takes the cue from the word "alleluia" to make a reflection on the mystery of the Ascension of Christ, his mission on earth, his preaching of the truth, the heavenly seat, and the praising of the angelic ranks. ${ }^{4}$

2 L. Nardini, Chants, Hypertext, and Prosulas: Re-Texting the Proper of the Mass in Beneventan Manuscripts, Oxford-New York 2021.

3 A full discussion of the epistemological similarities between hypertexts and prosulas is in Chapter 1 of my Chants, Hypertext, and Prosulas.

4 As a general introduction to tropes and prosulas see Embellishing the Liturgy: Tropes and Polyphony, ed. A.E. Planchart, Farnham 2009 (Music in Medieval Europe). 


\section{Example 1}

Benevento, Biblioteca Capitolare, 40, 68v. Reproduced with permission.

The beginning of prosula Allevatus dominus for the Alleluia Tu es latissimus for the feast of the Annunciation.

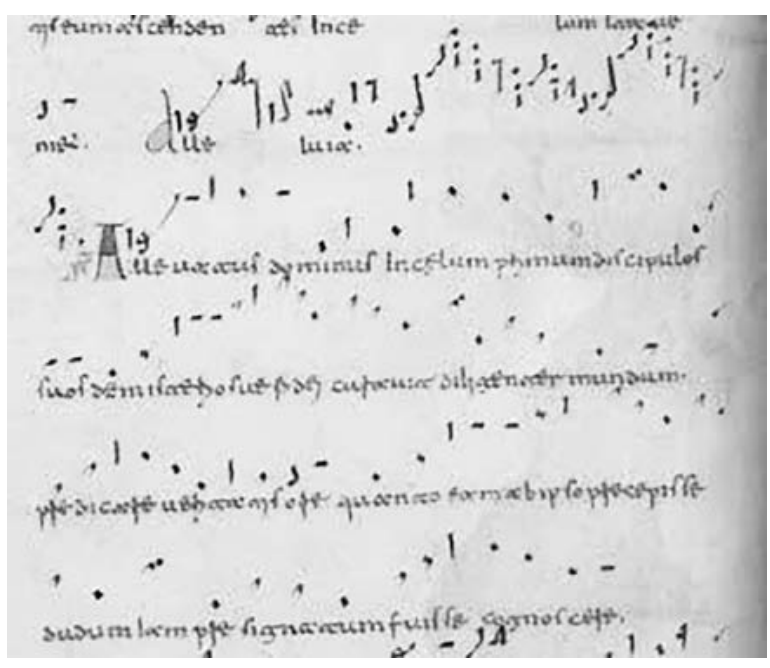

Example 1 shows a detail from the manuscript Benevento, Biblioteca Capitolare 40, a gradual that was probably copied at the abbey of Santa Sofia in Benevento during the first half of the eleventh century. It displays the typical script and notation of Beneventan manuscripts, which were produced in a large region of medieval southern Italy, including the former Lombard duchy and some other territories that were under the influence or domain of Byzantines, Normans, and the Papacy between the ninth and the thirteenth centuries. Some of the most important centers of this region include Benevento, Montecassino, Naples, and Salerno. This area reaches as far north as the Abruzzi region and as far east as the eastern shores of the Adriatic in modern Dalmatia and Albania. ${ }^{5}$

5 There is a substantial bibliography on Beneventan manuscripts and on regional script and notation. Classic studies include E.A. Loew, The Beneventan Script: A History of the South Italian Minuscule. Text, $2^{\text {nd }}$ ed. prepared and enl. by Virginia Brown, vol. 1, 2 vols., Roma 1980 (Sussidi Eruditi, 33-34); Le Codex VI. 34 de la Bibliothèque Capitulaire de Bénévent (XIe-XIIe siècle): Graduel de Bénévent avec prosaire et tropaire, Solesmes 1957, p. 15 (Paléographie Musicale, 15). A recent, comprehensive discussion of Beneventan neumes is in T.F. Kelly, M.G. Peattie, The Music of the Beneventan Rite, Bärenreiter 2016 (Monumenta Monodica Medii Aevi, 9). Several Beneventan manuscripts are published in facsimile edition, especially in the 
Similarly to other liturgical repertories of medieval southern Italy, prosulas are significant under many respects. They allow us to detect the multicultural influences of an area with a highly diversified population. Romans, Byzantines, Lombards, Normans, Franks, Jews, and Muslims were present in the region at different times and with different political roles and all left their marks on the local cultural production, including the liturgical music used for the rites of the Latin Church. ${ }^{6}$ These interconnections are evident in some musical and textual features of chants, such as the preference for wave-like contours and the employment of tune-families (typical traits of many Mediterranean musical cultures), as well as some saints' cults that catalyzed the influence of these different ethnic groups. St Michael is such an example in his being a holiest figure for Lombards, Greeks, and Jews, and in his conveying elements of pre-Christian, Pagan cults developed within and beyond the Italian peninsula. ${ }^{7}$ Nuns were also active participants in this musical and liturgical production, since manuscript tied to nunneries, especially those of St Peter inside the Walls and St Peter outside the Walls in the city of Benevento, present several exemplars of these chants. ${ }^{8}$

series "Paléographie musicale". Les principaus manuscrits de chant grégorien, ambrosien, mozarabe, gallican, publiés en fac-similés phototypiques par les Bénédictines de Solesmes under the direction of André Mocquereau (voll. I-XIII), Joseph Gajard (voll. XIV, XVIII), and Jacques Froger (from vol. XIX), Solesmes 1889. The facsimile of Benevento 40 is published in: Benevento, Biblioteca Capitolare 40, Graduale, a cura di A. Turco, N. Albarosa, Padova 1991 (Codices Gregoriani, 1).

6 On the musical traditions of the Beneventan region see: T. Forrest Kelly, The Beneventan Chant, Cambridge 1989; L. Nardini, Interlacing Traditions: Neo-Gregorian Chants Propers in Beneventan Manuscripts, Toronto 2016 (Monumenta Liturgica Beneventana, 8).

7 G. Otranto, C. Carletti, Il Santuario Di S. Michele Arcangelo Sul Gargano Dalle Origini al X Secolo, Bari 1990; A. Galdi, E. Susi, Santi, navi e saraceni. Immagini e pratiche del mare tra agiografia e storia delle coste campane a quelle dell'Alto Tirreno (secoli VI-XI), "Quaderni di storia religiosa” 14 (2009), p. 53-102; L. Nardini, The Diffusion of Gregorian Chant in Southern Italy and the Masses for St Michael, in: Music and World Christianities, eds. J. Dueck, S. Reily, Oxford 2016, p. 581-605.

8 Discussion of the connections between the manuscripts Benevento, Biblioteca Capitolare 35 and 39 and the monasteries of St Peter Inside and St Peter Outside the Walls is in: L. Nardini, The St Peter Connection and the Acquisition of a Roman Offertory in Bologna and Benevento, "Mediaeval Studies" 82 (2010), p. 39-74; L. Nardini, Interlacing Traditions: Neo-Gregorian Chants Propers in Beneventan Manuscripts, Toronto 2016 (Monumenta Liturgica Beneventana, 8); L. Nardini, Chants, Hypertext, and Prosulas: Re-Texting the Proper of the Mass in Beneventan Manuscripts. Other studies that have considered the possibility that these manuscripts were copied at these monasteries are: Beneventanum Troporum Corpus I: Tropes of the Proper of the Mass from Southern Italy, A.D. 1000-1250. II Proper Chants and Tropes, a cura 
The website employs freely available platforms: Google Sites for the home page, informative pages (About the Director; About the Project; About the Team), and links to the database and digital edition; Caspio (www.Caspio.com) for the database to allow full search of the chants based on a variety of criteria (Example 2); and Digital Mappa (https://www.digitalmappa.org/) for annotated images of manuscripts (edited with Photoshop and Gimp) (Example 3), for musical transcriptions and for the edition of texts (Examples 4 and 5). This portion of the website is currently under construction with a projected publication date of December 2021.

\section{Example 2}

The search page of the database. It allows to search by text, feast, liturgical genre of the parent chant, and catalog numbers of various published editions.

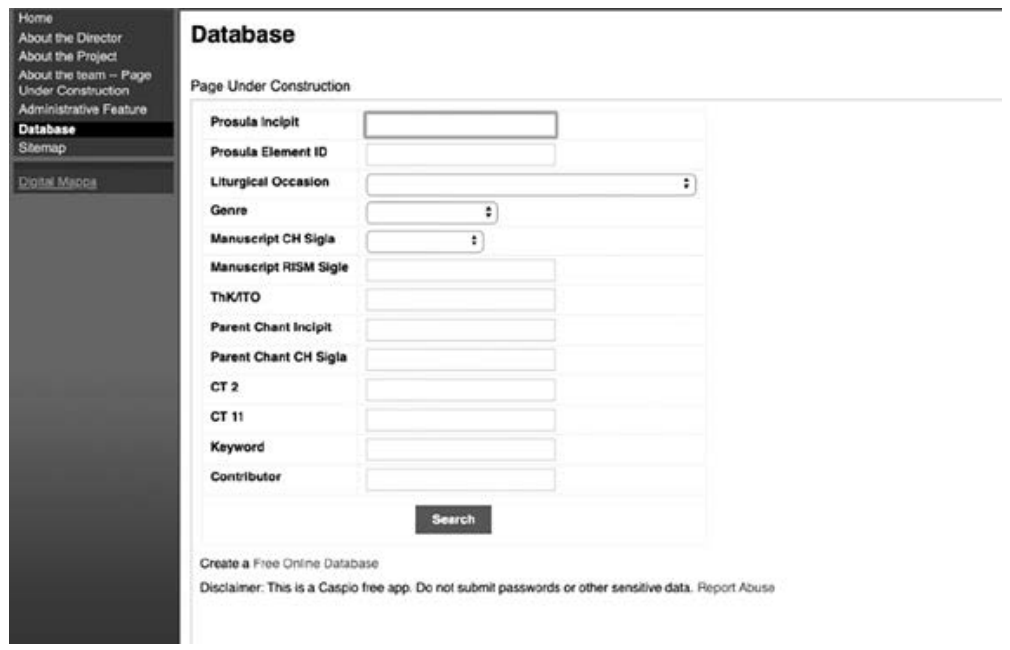

di A.E. Planchart, 2 vols., Madison 1994 (Recent Researches in the Music of the Middle Ages and Early Renaissance, 16-18); Beneventanum Troporum Corpus: The Ordinary of the Mass, ed. by J. Boe, Madison 1989 (Recent Researches in the Music of the Middle Ages and Early Renaissance, 19-23). 


\section{Example 3}

Benevento, Biblioteca Capitolare, 38, 164. [Reproduced with permission.]

The prosula Sancte vir prudens for the Alleluia Beate confessor is here shown in an edited version, so that script and notation appear as black signs on a white background. The image is shown without the annotations that will appear in the website.

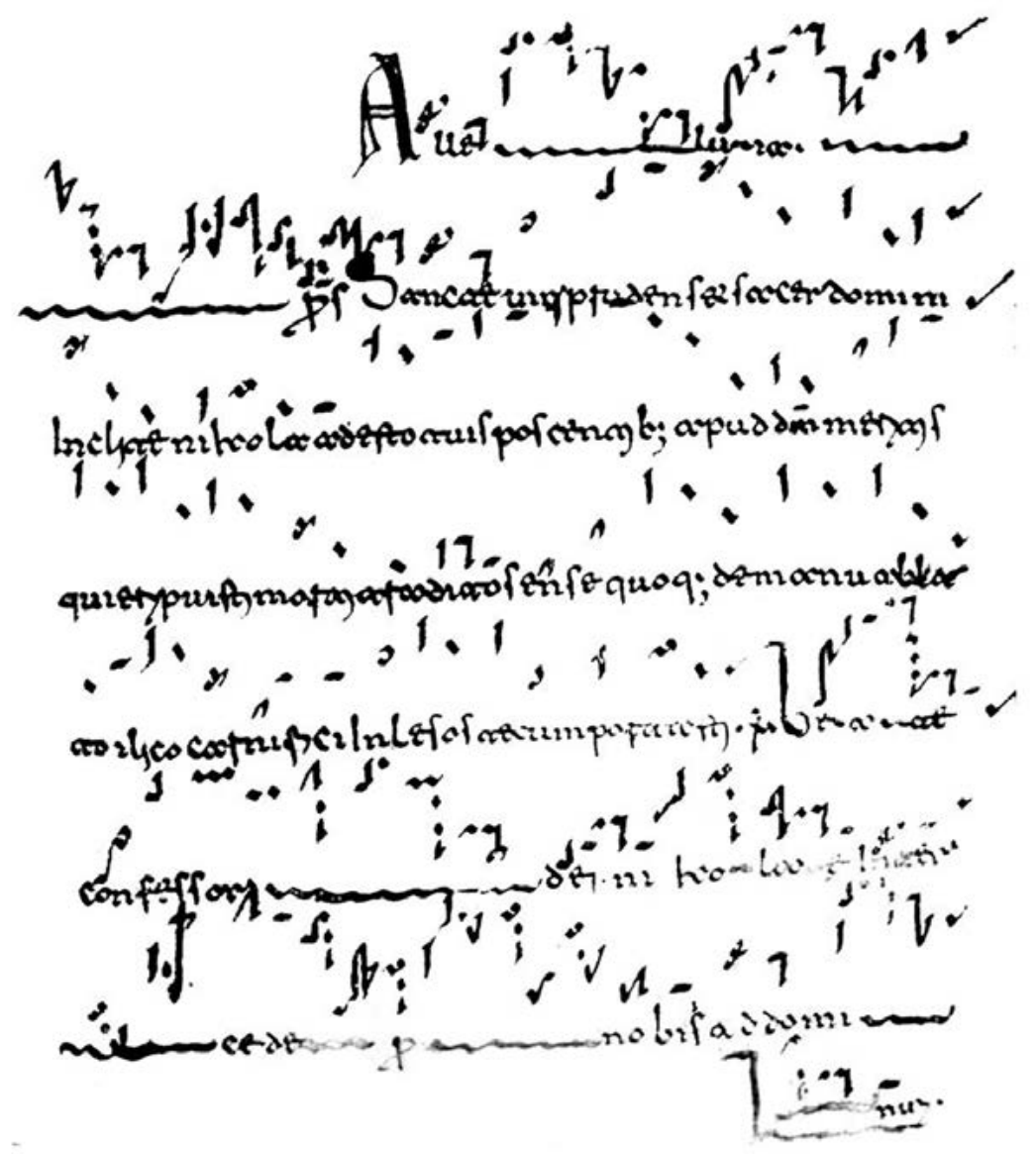




\section{Example 4}

The prosula Sancte vir prudens transcribed in modern notation.

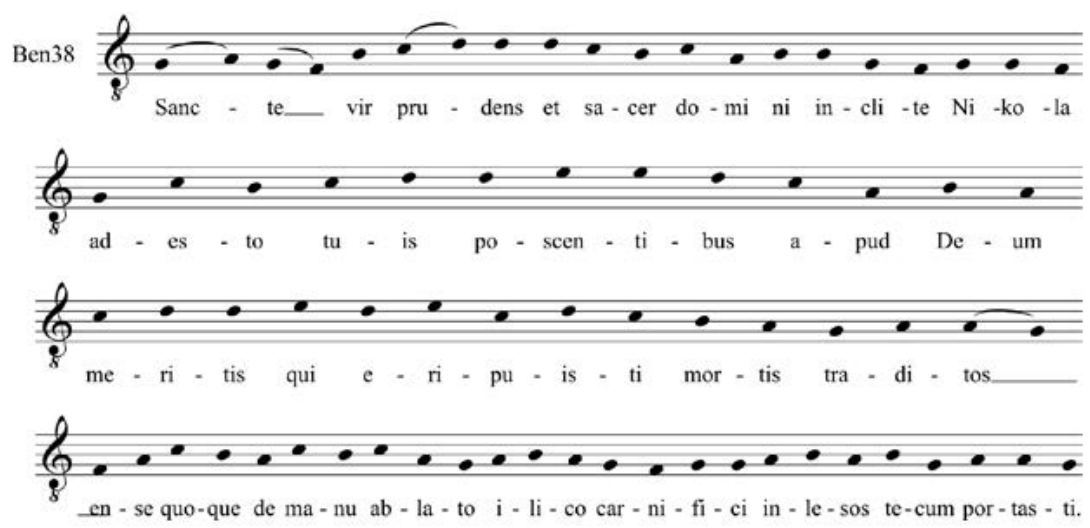

\section{Example 5}

Textual transcription of the prosula Sancte vir prudens with its parent chant Beate confessor Dei.

The box includes full textual transcription of the prosula and parent chant (in small caps); the chant siglum (AL-6); reference to the melody of the parent chant (ThK403) based on the thematic catalog of medieval alleluias; ${ }^{9}$ reference to the liturgical feasts in which the chant is sung (M 202; M 434.4) according to the catalog of the Biblioteca Capitolare of Benevento; ${ }^{10}$ and reference to the manuscript and folio number (Ben38, 164v).

9 K.-H. Schlager, Thematischer Katalog der ältesten Alleluia-Melodien aus Handschriften des 10. und 11. Jahrhunderts, ausgenommen das ambrosianische, alt-römische und alt-spanische Repertoire, München 1965 (Erlanger Arbeiten zur Musikwissenschaft, 2).

$10 \mathrm{~J}$. Mallet, A. Thibaut, Les manuscrits en écriture bénéventaine de la Bibliothèque capitulaire de Bénévent, vol. 2-3, Ottawa 1997. 


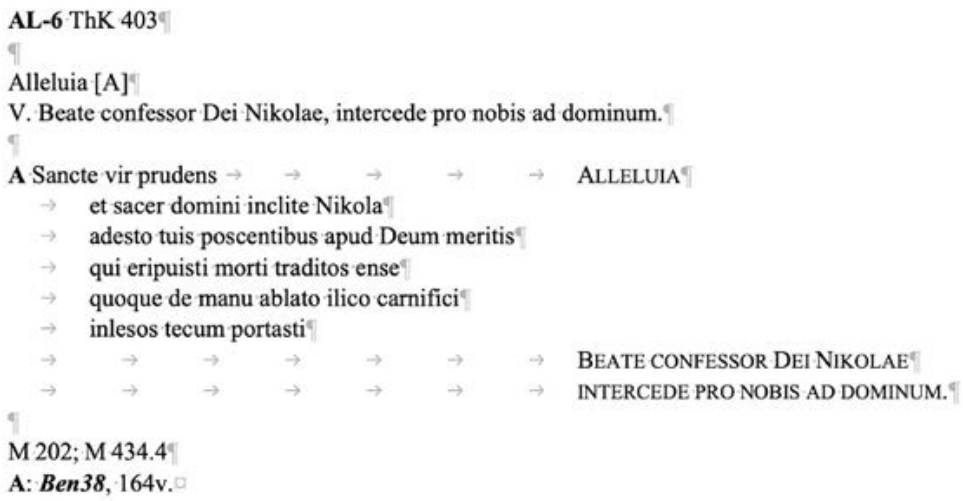

As mentioned above, a website on medieval chant can help to redefine our knowledge of medieval chant in multiple ways, under morphological, authorial, and thematic standpoints, while also providing useful opportunities for reflection on the ethics of digital publishing.

First, it allows to bring back to life the creativity of cantors from peripheral areas. Prosulas show the continuous balance between conformity to a centralized repertory of chant and the will to preserve elements of the local musical and religious life. In turn, prosulas show the fluidity of liturgical Latin that was morphing into a proto-Italian language (or other pre-Romance ones). For this reason, the edition does not standardize the texts, so that historians of the language and literature can reconstruct linguistic fluctuations.

Second, it provides details about the involvement of nuns in the creation and diffusion of the repertory. Although studies in musicology have been increasingly recognizing the role of nuns in the composition and transmission of music, Benedictine nuns (at least up until the late $13^{\text {th }}$ century) are generally considered as passive receivers of chant and book production with the major exception of Hildegard of Bingen. ${ }^{11}$ My research shows not only that nuns were able to compose and transcribe their own chants, but also that they were active participants in the social and cultural life of the city and in constant contact with their male counterparts. This is demonstrated by exclusive borrowings from multiple manuscripts that were used at male establishments within the same city.

11 Although not specific about chant, A.I. Beach, Women as Scribes: Book Production and Monastic Reform in Twelfth-Century Bavaria, Cambridge 2004 (Cambridge Studies in Paleography and Codicology, 10), provides a useful critical evaluation and several case studies of the role of nuns in book production. 
Based on cultic, archeological, and paleographical evidence these borrowings can only be explained by positing the notion of a "diffused" scriptorium within the city for which books could be borrowed among several institutions. ${ }^{12}$ This notion drastically challenges the commonly accepted narrative of the scriptorium as a self-contained space in which (mostly) monks worked in isolation copying from a single source. ${ }^{13}$

Third, it highlights the cultural implications of saints' cults. In southern Italy, early saints from Africa and West Asia (especially apostles and early martyrs) were deemed as more prestigious than local and contemporary ones because they were perceived as closer to the historical and geographical source of Christianity. ${ }^{14}$

Finally, the website strives to acknowledge all contributors with sigla and an "About the Team" page (under construction). These include, to date, the webmasters (Zacharia Benalayat, ZB; Kyrie Bouressa, KB; and Logan Cooley, LC), collaborators (Emily Loeffler, EL, and Bibiana Vergine, BV), editors (Abigail Adams, AA; Caroline Bowers, CCB; Kyrie Bouressa, KB; Benjamin Coghan, BJC; Flannery Jamison, FHJ; Aruna Kharod, AK; Amelia McElveen, ACM; Jordyn Middleton, JEM; Cristina Saltos, CRS; and Elizabeth Seay, ES; Jackson Wilds, JW), and consultants (Allyssa Guzman, AG, Jessica Trelogan, JT). In this way, the website tackles the questions of "ethical collaboration" by being fully transparent about its contributors.

The ultimate commitment of this website, thus, is to give full voice to the artists (men and women) of the past and to the scholars and technicians of today by also offering an opportunity to reflect on ways in which medieval and modern epistemologies intersect and illuminate one another.

12 L. Nardini, Interlacing Traditions: Neo-Gregorian Chants Propers in Beneventan Manuscripts, p. 86.

13 This thought was strongly inspired by Rosamond McKitterick, see: Carolingian Culture: Emulation and Innovation, ed. R. McKitterick, Cambridge 1994.

14 A. Vuolo, Agiografia beneventana, "Campania Sacra" 25 (1995), p. 261-92; A. Galdi, E. Susi, Santi, navi e saraceni. Immagini e pratiche del mare tra agiografia e storia delle coste campane a quelle dell'Alto Tirreno (secoli VI-XI), "Quaderni di storia religiosa" 14 (2009), p. 53-102; L. Nardini, Chant, Hypertexts, and Prosulas: Re-Texting the Proper of the Mass in Beneventan Manuscripts, Oxford 2021. 


\section{Abstract}

Medieval Chant and Digital Technology:

A Website for Liturgical Prosulas

Chants Hypertexts is a companion website for a forthcoming book that is a study and edition of a substantial body of liturgical music from medieval southern Italy, that of the prosulas of the Proper of the Mass included in the so-called Beneventan manuscripts. This repertory is significant under many points of view. It allows us to detect the many multicultural influences of an area with a highly diversified population. Romans, Byzantines, Lombards, Normans, Franks, Jews, and Muslim were present in the region at different times and with different political roles. They all left their marks on its cultural production, including the liturgical music used for the rites of the Latin Church and women, in particular nuns, were active participants in this musical and liturgical production.

In addition to addressing the issue of female creativity, the website also tackles the questions of "ethical collaboration" by being fully transparent about its contributors. This way the website will show its commitment to give full voice to the artists of the past and to the scholars and technicians of today.

Keywords: prosulas, tropes, Beneventan manuscripts, Digital Humanities, ethical collaboration.

\section{Abstrakt \\ Średniowieczny śpiew i technologia cyfrowa: \\ Strona internetowa dla prosul liturgicznych}

Chants Hypertexts to strona internetowa towarzysząca oczekiwanej książce, która jest studium i edycją znaczącego korpusu muzyki liturgicznej ze średniowiecznych południowych Włoch, prozopli mszalnych zawartych $\mathrm{w}$ tzw. manuskryptach benewenckich. Repertuar ten jest znaczący z wielu punktów widzenia. Pozwala nam na wykrycie wielu wielokulturowych wpływów na obszarze o bardzo zróżnicowanej populacji. Rzymianie, Bizantyjczycy, Lombardowie, Normanowie, Frankowie, Żydzi i muzułmanie byli obecni w tym regionie w różnym czasie, pełniąc różne role polityczne. Wszyscy oni odcisnęli swoje piętno na jego produkcji kulturowej, w tym na muzyce liturgicznej używanej w obrzędach Kościoła 
łacińskiego, a kobiety, a w szczególności zakonnice, były aktywnymi uczestniczkami tej muzycznej i liturgicznej produkcji.

Poza podjęciem tematu kobiecej kreatywności, strona porusza również kwestię „etycznej współpracy” poprzez pełną przejrzystość w odniesieniu do współpracowników. W ten sposób strona pokaże swoje zaangażowanie w oddanie pełnego głosu artystom z przeszłości oraz dzisiejszym naukowcom i technikom.

Stowa kluczowe: prosulae, tropi, manuskrypty benewenckie, Digital Humanities, etyczna współpraca

\section{Bibliography}

Benevento, Biblioteca Capitolare 40, Graduale, a cura di A. Turco, N. Albarosa, Padova 1991 (Codices Gregoriani, 1).

Galdi A., Susi E., Santi, navi e saraceni. Immagini e pratiche del mare tra agiografia e storia delle coste campane a quelle dell'Alto Tirreno (secoli VI-XI), "Quaderni di storia religiosa" 14 (2009), p. 53-102.

Kelly T.F., Peattie M.G., The Music of the Beneventan Rite, Bärenreiter 2016 (Monumenta Monodica Medii Aevi, 9).

Le Codex VI. 34 de la Bibliothèque Capitulaire de Bénévent (XIe-XIIe siècle): Graduel de Bénévent avec prosaire et tropaire, Solesmes 1957 (Paléographie Musicale, 15).

Loew E.A., The Beneventan Script: A History of the South Italian Minuscule. Hand List of Beneventan Manuscripts, $2^{\text {nd }}$ ed. prepared and enl. by Virginia Brown, 2 vols., Rome 1980 (Sussidi Eruditi, 33-34).

Mallet J., Thibaut A., Les manuscrits en écriture bénéventaine de la Bibliothèque capitulaire de Bénévent, vol. 2-3, Ottawa 1997.

McKitterick R., Script and Book Production, in: Carolingian Culture: Emulation and Innovation, 221-47, New York 1994.

Nardini L., The Diffusion of Gregorian Chant in Southern Italy and the Masses for St Michael, in: Music and World Christianities, eds. J. Dueck, S. Reily, Oxford 2016, p. 581-605.

Nardini L., Interlacing Traditions: Neo-Gregorian Chants Propers in Beneventan Manuscripts, Toronto 2016 (Monumenta Liturgica Beneventana, 8).

Nardini L., Chant, Hypertexts, and Prosulas: Re-texting the Proper of the Mass in Beneventan Manuscripts, Oxford-New York 2021.

Otranto G., Carletti C., Il Santuario Di S. Michele Arcangelo Sul Gargano Dalle Origini al X Secolo, Bari 1990.

Embellishing the Liturgy: Tropes and Polyphony, ed. A.E. Planchart, Farnham 2009 (Music in Medieval Europe). 
Paléographie musicale. Les principaus manuscrits de chant grégorien, ambrosien, mozarabe, gallican, publiés en fac-similés phototypiques par les Bénédictines de Solesmes under the direction of André Mocquereau (voll. I-XIII), Joseph Gajard (voll. XIV, XVIII), and Jacques Froger (from vol. XIX), Solesmes 1889.

Schlager K.-H., Thematischer Katalog der ältesten Alleluia-Melodien aus Handschriften des 10. und 11. Jahrhunderts, ausgenommen das ambrosianische, alt-römische und alt-spanische Repertoire, München 1965 (Erlanger Arbeiten zur Musikwissenschaft, 2).

Vuolo A., Agiografia beneventana, „Campania Sacra” 25 (1995), p. 261-92. 